\title{
Dissolved Free and Combined Carbohydrates During a Phytoplankton Bloom in the Northern North Sea
}

\author{
Venugopalan Ittekkot ${ }^{1}$, Uwe Brockmann ${ }^{2}$, Walter Michaelis ${ }^{1}$ and Egon T. Degens ${ }^{1}$ \\ ${ }^{1}$ SCOPE/UNEP International Carbon Unit, Geologisch-Paläontologisches Institut, Universität Hamburg, Bundesstraße 55, \\ D-2000 Hamburg 13, Federal Republic of Germany \\ 2 Institut für Organische Chemie und Biochemie, Universität Hamburg, Martin-Luther-King-Platz 6, D-2000 Hamburg 13, \\ Federal Republic of Germany
}

\begin{abstract}
Variations in dissolved free and combined carbohydrates during a phytoplankton bloom in the northern North Sea were investigated. Large amounts of carbohydrates are released into seawater during the bloom; the major portion of this release occurs towards the end of the bloom. A considerable part of the released carbohydrates is in the combined form. Free dissolved carbohydrates are formed mainly by in situ hydrolysis of dissolved combined carbohydrates. Glucose and fructose dominate the free dissolved carbohydrate fraction. Glucose is formed biologically, and fructose biologically and abiotically from glucose. Glucose comprises more than $60 \%$ of the combined carbohydrate fraction, followed by mannose, galactose and xylose. The production and release of dissolved carbohydrates in large amounts appear to be related to the availability of nutrients. The vertical distribution of dissolved carbohydrates is controlled by boundary layers in mid-water.
\end{abstract}

\section{INTRODUCTION}

Dissolved organic matter (DOM) represents the largest pool of organic matter in the sea (Mopper and Degens, 1979), more than $60 \%$ of which remains uncharacterised (Degens, 1970; Williams, 1975). Carbohydrates and amino acids belong to those compounds already identified (Degens et al., 1964). They belong to the labile fraction of marine DOM and are directly associated with biogeochemical processes taking place in the marine environment (Bada and Lee, 1977). These compounds are rapidly recycled. Studies directed towards understanding the processes controlling their distribution in the marine environment should include space-time investigations, especially with respect to biological events controlling their production and alteration. In addition, measurements of other physical and chemical biological parameters should be made in order to understand their influence on formation of DOM in the marine environment. In this paper we report results of carbohydrate analysis obtained from samples collected during the Fladen Ground Experiment (FLEX 1976) in the northern North Sea
The experiment was conducted within a $100 \mathrm{~km}$ side square; it covered a 3 month period from mid-March to mid-June 1976. A series of physical, chemical and biological measurements were made in situ in the entire water column $(0-150 \mathrm{~m})$ at intervals of 2 to $6 \mathrm{~h}$. Some critical data from the central station $\left(58^{\circ} 55^{\prime} \mathrm{N}\right.$, $0^{\circ} 32^{\prime} \mathrm{E}$ ) are depicted in Figure 1. They are pertinent to the discussion of data presented in this report.

\section{SAMPLE MATERIALS}

Water samples from the entire water column were collected at the central station using Niskin samplers. Sea water was filtered using Whatman GF/C filters (retention capacity $1.2 \mu \mathrm{m}$ ), fixed with $\mathrm{HgCl}_{2}$, and stored at $4^{\circ} \mathrm{C}$ until laboratory analysis. Detailed background data for samples can be found elsewhere (Brockmann et al., 1977a). Six vertical profiles collected at different time intervals were chosen for the analyses of dissolved free and combined carbohydrates. The samples were chosen so as to characterise biochemically the main stages of the phytoplankton bloom: (a) 26. 3. 1976 - a thoroughly mixed water 


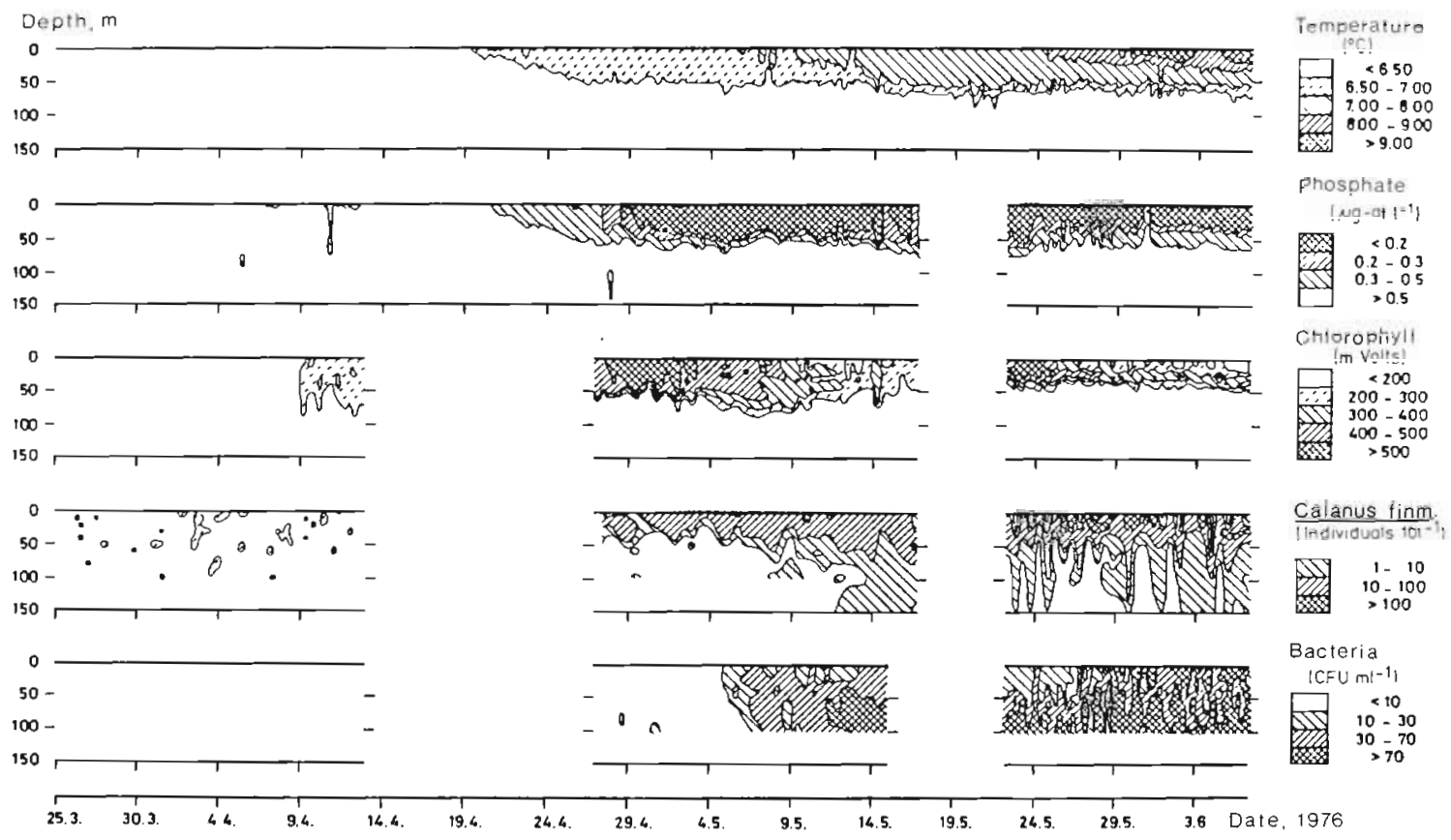

Fig. 1. Depth and time profiles of water temperature, phosphate, chlorophyll, Calanus finmarchicus, and colony-forming bacteria (CFU) at a central station of the FLEX box positioned in the center of the North Sea (58 $55^{\prime} \mathrm{N}, 0^{\circ} 32^{\prime}$ E). Note that for graphical reasons the contour pattern of phosphate concentration is light at high and dark at low concentration. (From 'Meeresforschung in Hamburg'; illustrated documentation of the 'Sonderforschungsbereich 94' at the University of Hamburg, FRG, 1977)

column, without any increase in phytoplankton; (b) 24 4. 1976 - early development of a phytoplankton bloom in a stratified water column; (c) 2.5. 1976 - main phytoplankton bloom (chlorophyll maximum)i (d) 15. 5. 1976 - regeneration mode; (e) 25. 5. 1976 - second phytoplankton bloom; and (f) 4.6,1976-period marking the end of the experiment.

\section{METHODS}

100 to $200 \mathrm{ml}$ of seawater were desalted by electrodialysis using ion exchange membranes. Part of the desalted sample was evaporated to dryness, the residue taken up in a known volume of distilled water and analysed for free dissolved carbohydrates. The other part of the desalted sample was hydrolysed using $1.8 \mathrm{n} \mathrm{HCl}$ at $100^{\circ} \mathrm{C}$ for $3.5 \mathrm{~h}$ under nitrogen. The hydrolysate was evaporated to dryness, the residue washed free of acid and taken up in a known amount of distilled water. Aliquot of this was analysed for total dissolved carbohydrates. The combined dissolved carbohydrates were calculated by substracting the free dissolved carbohydrates from the total fraction. Separation and identification of carbohydrates were carried out on an automatic sugar analyser (Biotronik, Frankfurt, FRG). For methodological details consult Mopper (1978).

\section{RESULTS}

\section{TotaI Dissolved Carbohydrates}

The concentration of total dissolved carbohydrates (TDCH) (free and combined) varied in the range of 40 to $400 \mu \mathrm{g} \mathrm{l}^{-1}$ (Fig. 2). Maximum concentrations occurred towards the end of the bloom (Fig. 2c). Their distribution in a thoroughly mixed water column remained rather uniform with values below $150 \mu \mathrm{g} \mathrm{l}^{-1}$ Of special interest was the spatial distribution of $\mathrm{TDCH}$ with regard to the depth of their concentration maxima in a stratified water column. In each of the analysed profiles maxima were recorded near or at the thermocline.

\section{Dissolved Combined Carbohydrates}

Dissolved combined carbohydrates (DCCH) comprised more than $75 \%$ of the TDCH fraction during the main phytoplankton bloom, with concentrations between 180 and $360 \mu \mathrm{g} \mathrm{I}^{-1}$ (Fig. 3). Maximum concentrations were observed towards the end of the bloom After the main phytoplankton bloom the relative percentage was less than $60 \%$. Minimum concentrations were recorded below the thermocline with values less than $50 \mathrm{Mg} \mathrm{l}^{-1}$ (Fig. 3e). Glucose dominated the DCCH 


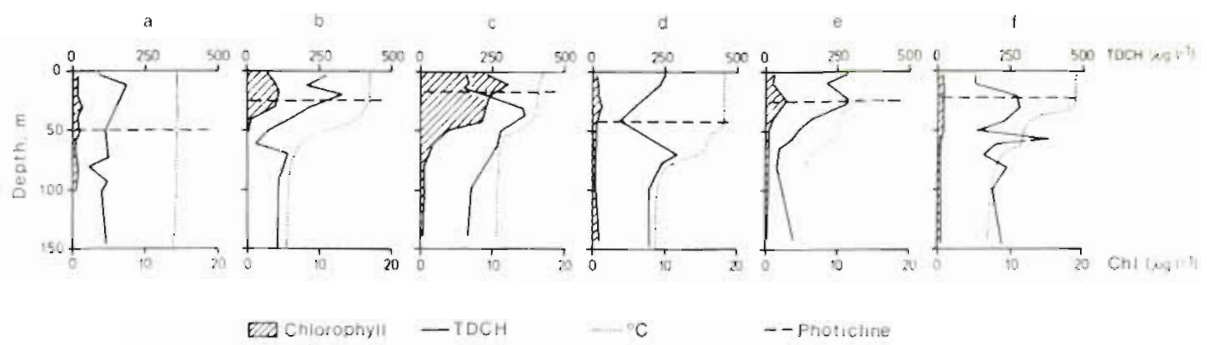

Fig. 2. Depth migration of thermocline and photicline (1\% light) as a function of time and the subsequent variations in the distribution pattern of chlorophyll (CHL) and total dissolved carbohydrates (TDCH) at the central station

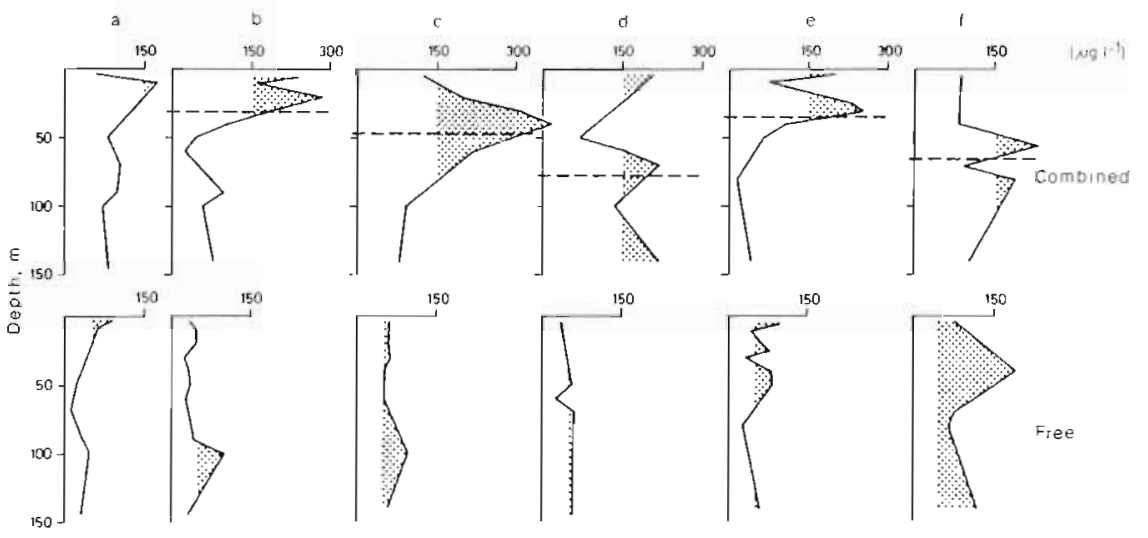

Fig. 3. Distribution of dissolved combined and dissolved free carbohydrates during FLEX with depth of thermocline

fraction (Fig. 4); it comprised more than $60 \%$ in most of the samples, followed by mannose, galactose, and xylose. Galactose and mannose were present in amounts around $20 \mu \mathrm{g} \mathrm{l}^{-1}$ throughout the experiment. However, their concentration maxima were separated in time: maximum concentration of mannose was found during the main phytoplankton bloom, those of galactose later. Xylose occurred in concentrations of ca. $10 \mu \mathrm{g} \mathrm{l}^{-1}$ in the upper layers during the main phytoplankton bloom. Rhamnose, ribose, arabinose and fucose were detected in minor quantities during periods following the bloom.

\section{Dissolved Free Carbohydrates}

Dissolved free carbohydrates (DFCH) were uniformly distributed during most of the experiment, with concentrations varying between 30 and $120 \mu \mathrm{g} \mathrm{l}^{-1}$ (Fig. 3). Higher concentrations up to $180 \mu \mathrm{g} \mathrm{l}^{-1}$ prevailed after the main phytoplankton bloom, especially towards the end of the experiment. The spectrum of DFCH was dominated by glucose and fructose, which comprised more than $90 \%$ of the total DFCH fraction (Fig. 5). The ratio glucose to fructose varied from 1.8 to 2.0 during the main phytoplankton bloom, to less than 1 to 1.2 after the bloom - especially towards the end of the experiment. Minor quantities of ribose, mannose and galactose were detected in the DFCH fraction of the analysed samples.
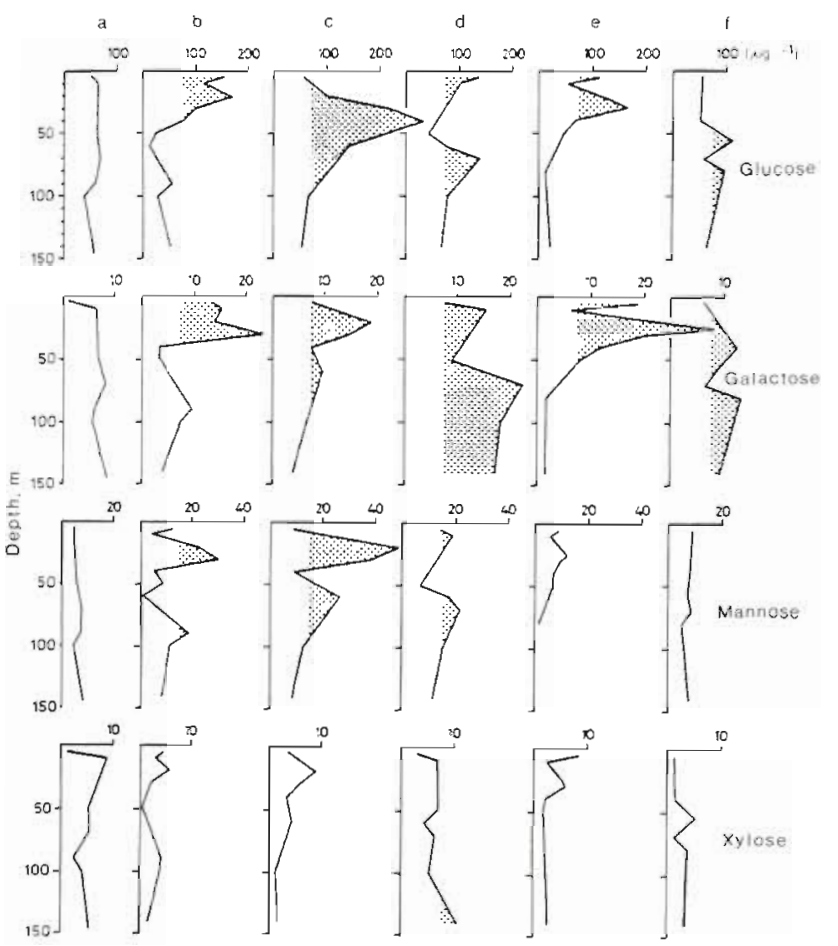

Fig. 4. Distribution of individual carbohydrates in the dissolved combined carbohydrate fraction 


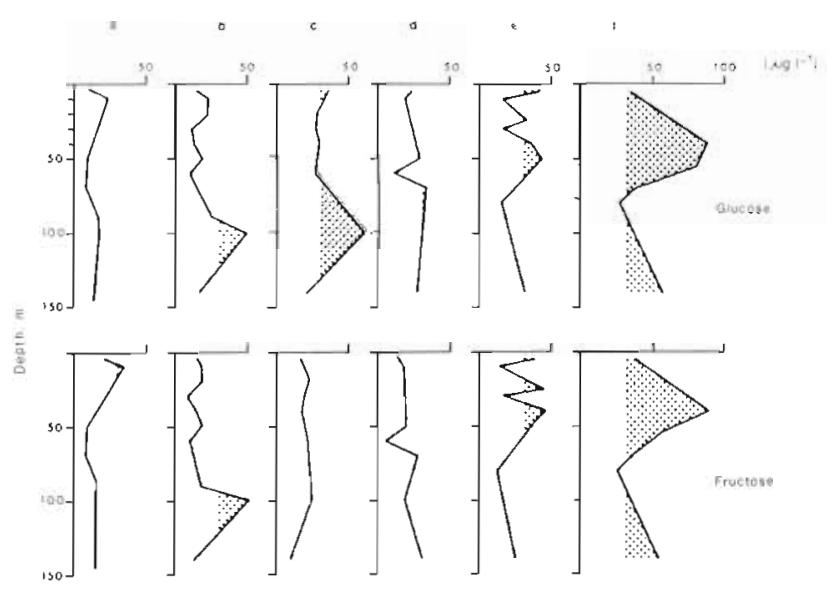

Fig. 5. Distribution of free dissolved glucose and fructose

\section{DISCUSSION}

The development of the phytoplankton bloom appears to have caused distinct variations in the concentrations of dissolved carbohydrates. The concentration range of $\mathrm{TDCH}, 40-400 \mu \mathrm{g} \mathrm{l^{-1 }}$, shows good agreement with published data from various marine environments (Walsh and Douglas, 1966; Handa, 1970). However, none of the published data deal with the variations in $\mathrm{DCCH}$ and $\mathrm{DFCH}$ in natural environments during a phytoplankton bloom.

Our results suggest that $\mathrm{DCCH}$ amounts increase with the development of the phytoplankton bloom, with maximum concentrations occurring towards the end of the bloom (Fig. 3c). It has been suggested previously that phytoplankton in culture releases dissolved organic matter at various stages of growth (Hellebust, 1965); maximum release was found to occur during the peak of a bloom and after it. In addition to this, data from culture and enclosure experiments also show that appreciable accumulation of carbohydrates in planktonic cells takes place at the end of their exponential growth phase (Guillard and Wangersky, 1958; Marker, 1965; Handa and Tominaga, 1969b; Myklestad et al., 1972; Brockmann et al., 1977b). An increase in carbohydrates released into the medium has also been observed especially following stagnation of biomass development. Phytoplankton liberates large quantities of polysaccharides under conditions of mineral deficiency. High glucose concentration in natural waters poor in nutrients is suggested to be a result of this (Vaccaro et al., 1968). During our experiment, increased amounts of carbohydrates appear in the water column simultaneously with a decrease in dissolved nutrients, especially nitrogen. The concentration of dissolved inorganic nitrogen was found to be below $1 \mu \mathrm{mol} \mathrm{l}^{-1}$ during this period (Eberlein et al., 1980). Thus low nutrient concentrations and the result- ing stagnation in the growth rates of phytoplankton have probably caused the accumulation of dissolved carbohydrates. In addition, cells sinking within the upper layer seem to release carbohydrates into the ambient seawater.

The decrease in DCCH concentrations after the main phytoplankton bloom may be caused by their decomposition via microbial degradation and enzymatic activity (Fig. 3d, e). The carbohydrates released by phytoplankton are an important food source for organotrophic bacteria (Williams and Yentsch, 1976). Work on the decomposition of carbohydrates in the past has shown that more than $60 \%$ of carbohydrates produced may be decomposed within a short period of time (Ogura and Gotoh, 1974). The results of our study suggest that a high percentage of $\mathrm{DCCH}$ released during the phytoplankton bloom is labile; these become easily hydrolysed in the marine environment (Handa and Yanagi, 1969).

The slight increase in DCCH during the second bloom is probably related to the release from phytoplankton dominating this bloom (see below; Fig. 3e). This bloom is restricted to the upper few meters of the water column by a secondary thermocline (Soetje and Huber, 1980) which prevented the influx of nutrients.

In summary, phytoplankton is expected to release minor amounts of carbohydrates as a normal physiological function. In contrast, sugar release in large quantities appears to be related to the availability of nutrients. The stagnation of plankton growth rates (stationary growth phase) through nutrient limitation leads to the production and release of large amounts of carbohydrates into the medium. Spilling of carbohydrates into seawater during grazing by zooplankton has also been suggested (Hellebust, 1967). The distribution of dissolved carbohydrates in the water column is controlled by the depth of the thermocline. Expressed differently, lysing cells and planktonic debris suspended close to the thermocline contribute significantly, to the dissolved carbohydrate pool in the marine environment.

The individual carbohydrates in the DCCH fraction have all been detected previously in seawater samples (Wangersky, 1952; Degens et al., 1964; Joseffson, 1970). Glucose, the major component of the DCCH fraction has also been shown to be a major monomer in phytoplankton and in samples collected from various natural environments (Walsh and Douglas, 1966; Handa and Tominaga, 1969). The highest concentrations of glucose observed towards the end of the bloom are probably due to massive release of storage polysaccharides, like, glucan, into seawater. High production of glucan by phytoplankton in stationary growth phase has also been reported (Antia et al., 1963; Brockmann et al., 1979). Galactose and mannose add up to more 
than $30 \%$ of the total carbohydrate fraction in diatoms (Hecky et al., 1973), and are present in their extracellular products (Allan et al., 1972), especially in Chaetoceros species (Haug and Myklestad, 1976). Separation of their concentration maxima in time is probably due to: (1) dominance of different phytoplankton species during FLEX, i. e. diatoms, mainly Chaetoceros species during the first bloom and flagellates during the second (Wandschneider, 1980), and (2) contribution of galactose-containing compounds by bacteria and zooplankton after the main phytoplankton bloom. Such compounds are present in organic matter derived from zooplankton (Degens and Mopper, 1976).

The uniform distribution of $\mathrm{d}$ issolved free carbohydrates (DFCH) during the main phytoplankton bloom suggests that they probably do not belong to compounds released in large amounts. Thus, the suggestion that phytoplankton excretes monomers in the first phase of release (Fogg et al., 1965) is perhaps not valid for the investigated carbohydrates. It is, however, conceivable that they are indeed released and rapidly utilised by heterotrophic populations. The higher concentrations towards the end of the bloom may result from in situ hydrolysis of polysaccharides. Such hydrolysis can take place either from dissolved organic matter or through release from degradation of particulate matter.

The dominance of glucose and fructose in the DFCH fraction seems to be a phenomenon characteristic of widely different environments (Liebezeit et al., 1980; Michaelis et al., 1980). Glucose may be expected to be released in large amounts by the in situ decomposition of glucans. The presence of fructose in amounts as large as those found in our study is noteworthy. It is probable that fructose and its polymers are important constituents of the carbohydrate fraction in marine organisms, especially flagellates, which dominate the second bloom. However, fructose was found to replace starch as a major food reserve only in some larger forms of chlorophycea (Percival, 1968). Detailed studies on carbohydrate composition of flagellates will be necessary before one can exclude a biological source for fructose. In the marine environment fructose may also be formed by the abiotic isomerisation of glucose (Mopper et al., 1980). Part of the fructose so formed will be utilised by heterotrophs and the rest stabilised by metal complexation, resulting in the enrichment of fructose in aged organic matter. The ability of fructose to form metal complexes is well documented (Charley et al., 1963; Barker et al., 1974). Indirect evidence for the existence of such complexes in natural environments is found in the dominance of fructose over glucose in pore waters enriched in iron (Mopper et al., 1980). The ratio glucose/fructose in the dissolved free carbohydrates is an indicator of the maturity of DOM in the deep sea, where extremely low glucose/fructose ratios (less than 0.8 ) are characteristic of water samples collected below $1000 \mathrm{~m}$ (Ittekkot, 1980). There, because of the resistance of DOM to biological degradation (Barber, 1968), abiotic processes may be expected to predominate.

\section{CONCLUSIONS}

The present study shows that boundary layers in midwater exert a remarkable influence on production and distribution of dissolved carbohydrates in the marine environment. The boundary layers may be unique in providing sites at which intensive inorganicorganic interactions can proceed. Such reactions have been suggested to be instrumental in the formation of stable organic matter in the marine environment (Degens and Matheja, 1967; Conover, 1978) which forms the bulk of DOM in the oceans.

Our results further suggest that information on DOM-dynamics in the marine environment can be obtained better by studying individual organic compounds like carbohydrates or amino acids, than by examining the total dissolved organic carbon (Ittekkot, 1980). Large amounts of carbohydrates are released into seawater during a phytoplankton bloom, with the major portion of this release taking place towards the end of the bloom. It is concluded that they are released mainly from cells under stress induced through changes in available nutrient concentrations and from lysing cells and planktonic debris suspended at the thermocline.

Most of the carbohydrates released during the bloom are in a combined form; efficient heterotrophic activity reduces their concentration to prebloom levels within a short time. The investigated carbohydrate monomers do not seem to be major primary excretion products of phytoplankton; rather they appear to be formed by the in situ hydrolysis of combined carbohydrates. The distribution pattern of individual carbohydrates reflects the various stages of a phytoplankton bloom, and the biological and abiotic processes controlling the formation and alteration of DOM in the marine environment. Abiotic processes, like isomerisation of glucose to fructose, are potentially useful in determining the age of marine DOM.

Acknowledgements. Chlorophyll data were kindly provided by A. Weber. We thank the German Research Council for financial support. JONSDAP ' 76 Contribution No. 56. 


\section{LITERATURE CITED}

Allan, G. G., Lewin, J and Johnson, P. G. (1972). Marine Polymers. IV Diatom Polysaccharides. Botanica Mar 15: 102-108

Antia, N. J., McAllister, C. D., Parsons, T. R., Stephens, K. and Strickland, J. D. H. (1963). Further measurements of primary production using a large volume plastic sphere. Limnol. Oceanogr. 8: 166-183

Bada, J. L., Lee, D. (1977). Decomposition and alteration of organic compounds dissolved in seawater. Mar. Chem. 5 : $523-534$

Barber, R. T. (1968). Dissolved organic carbon from deep waters resists microbial oxidation. Nature, Lond. 220 $274-275$

Barker, S. A., Somers, P. J., Stevenson, J. (1974). Redissolvable ferric-D-fructose and ferric-D-glucose-D-fructose complexes. Carbohydr. Res. 36: 331-337

Brockmann, U., Eberlein, K., Huber, K., Radach, G. and Schulze, K. (1977a). Draft FLEX Atlas, Sonderforsch. Bereich 94, Meeresforschung Hamburg Universität

Brockmann, U., Eberlein, K., Hentzschel, G., Schöne, H. Siebers,d., Wandschneider, K., Weber, A. (1977b). Parallel plastic tank experiments with cultures of marine diatoms. Helgol. wiss. Meeresunters. 30: 201-216

Brockmann, U., Eberlein, K., Junge, H. D., Maier-Reimer, E., Siebers, D. (1979). The development of a natural phytoplankton population in an outdoor tank with nutrient poor sea water. II. Changes in dissolved carbohydrates and amino acids. Mar. Ecol. Prog. Ser. 1: 283-291

Charley, P. J., Sarkar, B., Stitt, C. F. and Saltman, P. (1963). Chelation of iron by sugars. Biochim. biophys. Acta 69 313-321

Conover, R. J (1978). Transformation of organic matter. In: Kinne, O. (ed.) Marine ecology, Vol. IV, Dynamics. Wiley, Chichester, pp. 221-499

Degens, E. T (1970). Molecular nature of nitrogenous compounds in sea water and recent sediments. In: Hood, D. W. (ed.) Organic matter in natural waters. Inst. Mar. Sci., Univ. Alaska, Pub. No. 1: 77-106

Degens, E. T., Matheja, J. (1967). Molecular mechanisms on interaction oxygen coordinated metal polyhydra and biochemical compounds. Techn. Rep., Woods Hole Oceanogr. Inst. 57-67: $1-312$

Degens, E. T., Mopper, K. (1976). Factors controlling the distribution and early diagenesis of organic material in marine sediments. In: Riley, J. P., Chester, R. (eds) Chemical oceanography, 2nd ed. Vol. 6. Academic Press, London, New York, San Francisco, pp. 60-114

Degens, E. T., Reuter, J. H., Shaw, N. F. (1964). Biochemical compounds in offshore California sediments and sea waters. Geochım. cosmochım. Acta 28: 45-66

Eberlein, K., Kattner, G., Brockmann, U. and Hammer, K. D. (1980). Nitrogen and phosphorus in different water layers at the central station during FLEX 1976. 'Meteor' Forschungsergeb., (Reihe A) 22: 87-98

Fogg, G. E., Nalewajko, C. and Watt, W. D. (1965). Extracellular products of phytoplankton photosynthesis. Proc. R. Soc. (Ser. B) 162: 517-534

Guillard, R. R. L., Wangersky, P. J. (1958). The production of extracullular carbohydrates by some marine flagellates. Limnol. Oceanogr. 3: 449-454

Handa, N. (1970): Dissolved and particulate carbohydrates. In: Hood, D. W (ed.) Organic matter in natural waters. Inst. Mar. Sci., Univ. Alaska, Publ. No. 1: 129-152

Handa, N., Yanagi, K. (1969). Studies on water extractable carbohydrates of particulate matter from Northwest Pacific Ocean. Mar. Biol. 4: 197-207

Handa, N., Tominaga, H. (1969). A detailed analysis of carbohydrates in marine particulate matter Mar. Biol. 2 . 228-235

Haug, A., Myklestad, S. (1976). Polysaccharides of marine diatoms with special reference to Chaetoceros species, Mar. Biol. 34: 217-222

Hecky, R. E., Mopper, K., Kilham, P., Degens, E. T. (1973). The aminocid and sugar composition of diatom cell walls. Mar Biol. 19: 323-331

Hellebust, J. A. (1965). Excretion of some organic compounds by marine phytoplankton. Limnol. Oceanogr. 10: 192-206

Hellebust, J. A. (1967). Excretion of organic compounds by cultured and natural populations of marine phytoplankton. In: Lauff, G. H. (ed.) Estuaries. Publs Am. Ass. Advmt Sci. 83: 361-366

Ittekkot, V A. (1980). Verteilung von gelöstem organischem Kohlenstoff, gelösten Zuckern und Aminosäuren im Fladengrund, nordliche Nordsee (FLEX 1976). Ph. D. thesis, Universität Hamburg

Joseffson, B. (1970). Determination of soluble carbohydrates in sea water by partition chromatography after desalting by ion-exchange membrane electrodialysis. Analytica chim. Acta 52: 65-73

Liebezeit, G., Bölter, M. Brown, I. F., Dawson, R. (1980) Dissolved free amino acids and carbohydrates at pycnocline boundaries in the Sargasso Sea and related microbial activity. Oceanol. Acta 3: 357-362

Marker, A. F. H. (1965). Extracellular carbohydrate liberation. in the flagellates Isochrysis galbana and Prymnesium parvum. J. mar. biol. Ass. U. K. 45: 755-772

Michaelis, W., Ittekkot, V., Degens, E. I (1980). Amino acids and carbohydrates as indicators of sedimentation processes. In: Actes du Colloq., C.N.R.S. 293: 129-139

Mopper, K. (1978). Improved chromatographic separation on anion-exchange resins. III. Sugars in borate medium. Anal.Biochem. 87: 162-168

Mopper, K., Degens, E. T. (1979). Organic carbon in the ocean: Nature and cycling. In: Bolin, B., Degens, E. T., Kempe, S., Ketner, P. (eds) Global carbon cycle. Wiley, Chichester, pp. 293-316

Mopper, K., Dawson, R., Liebezeit, G. and Ittekkot, V. (1980). Monosaccharide spectra of natural waters. Mar. Chem. 10: $55-66$

Myklestad, S., Haug, A., Larsen, B. (1972). Production of carbohydrates by the marine diatom Chaetoceros affinis var. willei (Gran) Hustedt. II. Preliminary investigation of the extracellular polysaccharide. J. exp. mar. Biol. Ecol. 9: $137-144$

Ogura, N., Gotoh, T. (1974). Decomposition of dissolved carbohydrates derived from diatoms in lake Yuno-ko. Int. Revue ges. Hiydrobiol. 59: 39-47

Percival, E. (1968). Marine algal carbohydrates. In: Barnes, $H$. (ed.) Ocean. Mar Biol. Ann. Rev. 6: 137-161

Soetje, K. C., Huber, K. (1980. A compilation of data on the thermal stratification at the central station in the northern North Sea during FLEX '76. 'Meteor' Forschungsergebn. (Reihe A) 22: 69-77

Vaccaro, R. F., Hicks, S. E., Jannasch, H., Carey, F. G. (1968) The occurrence and role of glucose in sea water Limnol Oceanogr 13: 356-360

Walsh, G. E., Douglas, J. (1966). Vertical distribution of carbohydrates in the Sargasso sea off Bermuda. Limnol Oceanogr. 11: 406-408

Wandschneider, K. (1980). Die Artensukzession des Phytoplanktons während der Fruhjahrsblute 1976 im Fladen- 
grundgebiet (nördliche Nordsee). Mitt. Inst. Allg. Bot. Hamburg 17: $39-48$

Wangersky, P. J. (1952). Isolation of ascorbic acid and rhamnosides from sea water. Science, N. Y 115: 685

Williams, P. J. LeB (1975). Bilogical and chemical aspects of dissolved organic materials in seawater In: Rlley, J. P.,
Skirrow, G. (eds) Chemical oceanography, Vol. 2, 2nd ed. Academic Press, London, pp. 301-363

Williams, P. J. LeB., Yentsch, C. S. (1976). An examination of photosynthetic production, excretion of photosynthetic products, and heterotrophic utilisation of dissolved organic compounds with reference to results from a coastal subtropical sea. Mar. Biol. 35: 31-40

This paper was submitted to the editor; it was accepted for printing on January 22, 1981 